\title{
Status of water quality in Kathmandu valley
}

\author{
Timila Bhaba Singh \\ Ground Water Resources Development Project, \\ Babarmahal, Kathmandu, Nepal \\ (Email:timilasingh@hotmail.com)
}

\begin{abstract}
The surface and subsurface water of the Kathmandu valley has been severely contaminated by various pollutants since the last fifteen years. Many factors have played their role in polluting the rivers and wells of the valley. The water quality monitoring of the Bagmati River and its tributaries revealed a strong seasonal variation. Ammonia, nitrate, phosphate, dissolved oxygen, biological oxygen demand, chemical oxygen demand, and total suspended solids are the main determinants of river water pollution. Similarly, the water samples drawn from various deep tubewells, shallow wells, and springs reveal a remarkable contamination of groundwater. Most of the deep tubewells of the Kathmandu valley consist of a greater amount of ammonia and iron as well as higher turbidity and colour values than those of the WHO guideline values. The water analysis data of the Bagmati River and its tributaries show an increasing contamination trend in the densely populated areas. Minbhawan, The Hanumante Khola, Dhobi Khola, Tukucha, Teku, and the Bishnumati Khola are comparatively more polluted while the Nakhu Khola and Balkhu Khola are less contaminated. The quality of groundwater is also deteriorating day by day due to the inadequate precautions and facilities to treat sewage and wastewater.
\end{abstract}

\section{INTRODUCTION}

The Kathmandu valley, which includes several cities of historical importance, is suffering from various environmental problems. Water pollution is one of them. In this regard, surface water pollution is becoming a more concerned problem, which is quite evident in the Bagmati River as well as its tributaries. The river water quality has immensely deteriorated within the last fifteen years. The Bagmati River originates from the south face of the Shivapuri Hills, and flows through the city towards the Chobhar gorge (Fig. 1). It is fed by the monsoon rain, a number of streams, such as the Manohara, Hanumante, Dhobi Khola, Tukucha, Bishnumati, Nakhu, and Balkhu. The deterioration of river water quality in recent years is due mainly to a rapid population growth without proper urban planning. Uncontrolled disposal of untreated wastewater and sewage directly into the rivers has far surpassed their assimilative capacity. Also, uncontrolled withdrawal of sand from riverbeds has adversely affected the river ecosystem.

Another growing concern is the depletion of groundwater which is being used as an alternative source in supplementing the drinking water in the valley. This resource is being utilised since ancient times, as evident from the dug wells and stone spouts present at various places in the Kathmandu, Patan, and Bhaktapur cities. People of the valley are using this resource for their daily activities, as the Nepal Water Supply Corporation cannot fully meet their demand. About $26 \%$ of the total groundwater is withdrawn from private wells (Warner 2001) and most of them are very shallow and prone to contamination. The Nepal Water Supply Corporation is also utilising the groundwater resource through deep tubewells for daily supply of drinking water in the cities.

\section{WATER SAMPLES}

For the purpose of evaluating the surface water quality in the Kathmandu valley, samples were collected from various rivers and streams (Fig. 1). Along the Bagmati River, they were obtained at Gokarna, Jorpati, Pashupati, Minbhawan, Shankhamul, Thapathali, Teku, Sundarighat, and Khokana. Among the tributaries, water samples were taken from the Manohara, Hanumante, Dhobi Khola, Tukucha, Bishnumati, Nakhu, and Balkhu. The water samples represent the suburban sites lying in the upper reaches as well as the core city area and the southern outskirts of the valley.

For evaluating the groundwater quality, representative samples of about 39 deep tubewells (DTWs), 4 shallow tubewells (STWs), and a few springs and dug wells were collected from different parts of the valley (Fig. 2).

\section{WATER QUALITY MONITORING PROGRAMME}

The water quality monitoring has regularly been conducted by the Ground Water Resources Development Project (GWRDP) since 1999/2000. The surface water quality monitoring of the Kathmandu valley is a quarterly-based (pre-monsoon, monsoon, post-monsoon, and winter) 
Timila Bhaba Singh

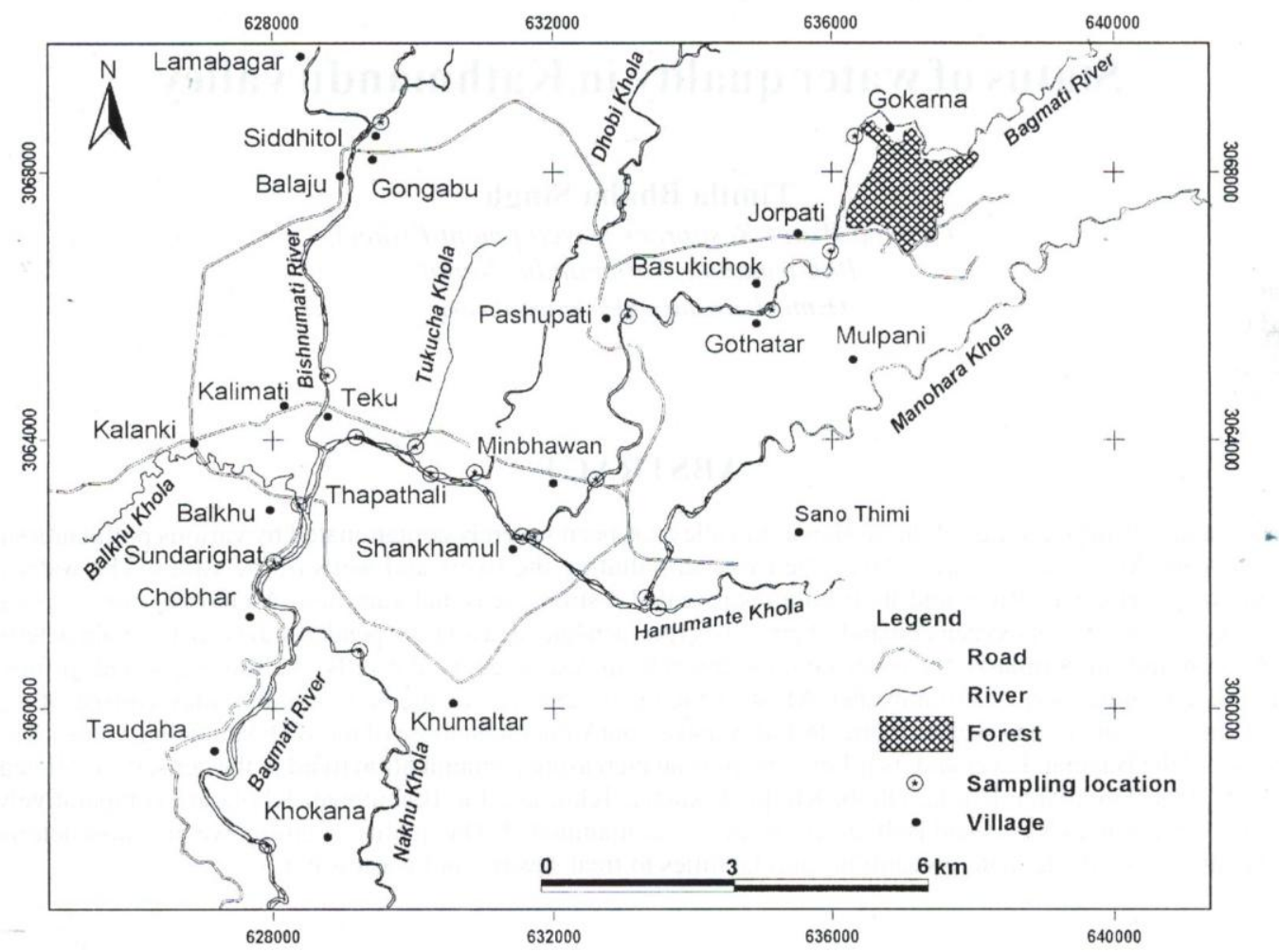

Fig. 1: Location of water samples from the Bagmati River and its tributaries in the Kathmandu valley

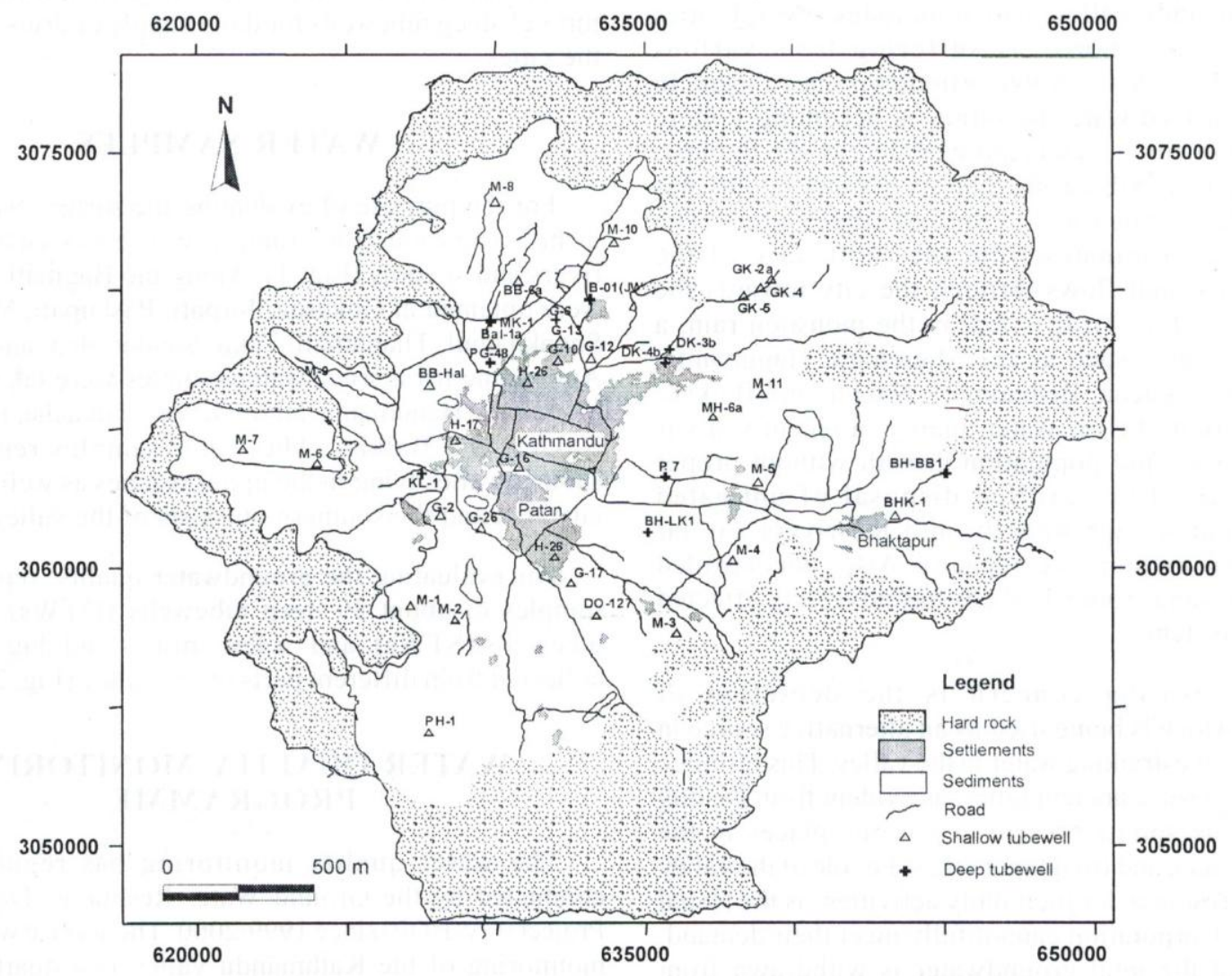

Fig. 2: Location of wells used for water sampling in the Kathmandu valley 
Table 1: Analytical methods adopted for various physical and chemical parameters

\begin{tabular}{l|l}
\hline \multicolumn{1}{c|}{ Analytical Methods } & \multicolumn{1}{c}{ Parameters } \\
\hline Instrumental Analysis & EC, pH, Temperature, DO, BOD \\
\hline $\begin{array}{l}\text { UV- spectrophotometric } \\
\text { methods }\end{array}$ & $\begin{array}{l}\text { Ammonia, Nitrate, Nitrite, } \\
\text { Sulphate, Phosphate, Colour, } \\
\text { Turbidity }\end{array}$ \\
\hline Titrimetric methods & $\begin{array}{l}\text { Total Hardness, Alkalinity, } \\
\text { Calcium, Chloride, COD }\end{array}$ \\
\hline Gravimetric methods & Total Suspended Solids (TSS) \\
\hline Membrane filter method & $\begin{array}{l}\text { Total coliform using Millipore } \\
\text { incubator for incubation. }\end{array}$ \\
\hline
\end{tabular}

programme, whereas the groundwater quality testing is a semi-annual (pre-monsoon and post-monsoon seasons) programme so as to study the seasonal variation in the water quality. This paper focuses on the water quality data of 20022003 (GWRDP 2002 a, b, c; GWRDP 2003 a, b, c).

\section{ANALYSIS AND RESULTS}

Water sampling and analysis was carried out following APHA et al. (1995). The analytical methods for each parameter are summarised in Table 1.

Water pollution may be because of physical, chemical, or biological factors. The dissolved and suspended chemicals are the domainant factors of pollution. The river water pollution in Kathmandu is mainly of anthropogenic type, which is due to the generation of sewage and wastewater from domestic, agricultural, or industrial use.

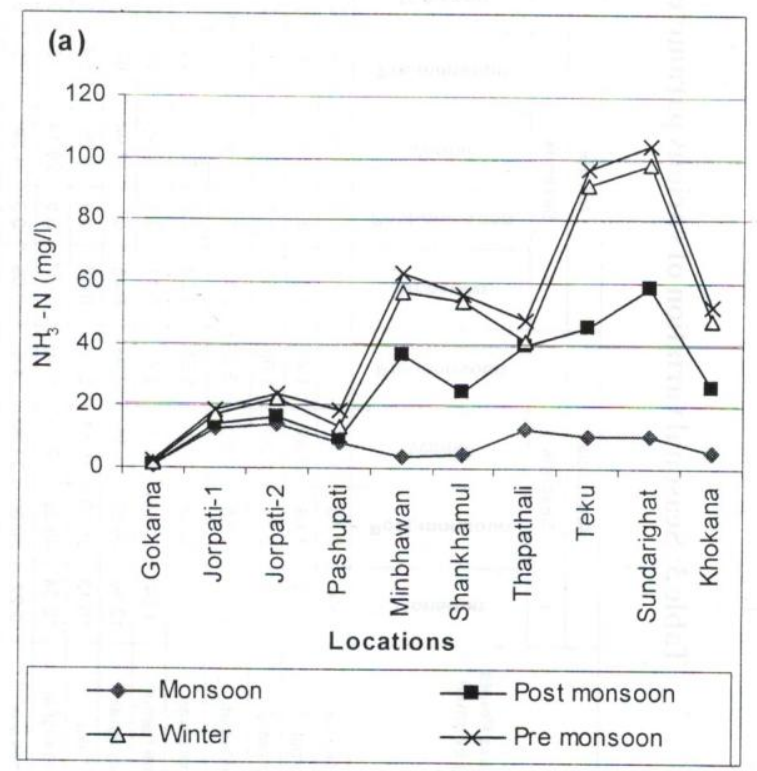

\section{STATUS OF RIVER WATER QUALITY}

Different physical and chemical parameters were analysed during the study, including the coliform tests. Almost all parameters show a fluctuation in the river water quality in all four seasons. The parameters such as ammonia, nitrate, dissolved oxygen (DO), biological oxygen demand (BOD), chemical oxygen demand (COD), and total suspended solids (TSS) are determinants of river water pollution. In general, the pollution level is lower in the upstream of the Bagmati River, but the level rises as the river flows through the core city area and its water quality does not improve in the downstream, as far as Khokana (Fig. 1).

There is a high concentration of ammonium ion in the soil. One of the causes of it could be due to the human and animal waste that in presence of oxygen undergoes ammonification by rapidly transforming organic nitrogen to ammonia. The Bagmati River has a high concentration of ammonia in all samples but the highest in the city area near Minbhawan, Shankhamul, Thapathali, Teku (Table 2) and among the tributaries, at Tukucha, Dhobi Khola, Kalimati of Bishnumati river (Table 3). The seasonal data show that the concentrations are higher in post-monsoon period (Fig. 3).

The nitrate concentration in river water is mainly due to the disposal of wastes and also due to the nitrification of ammonia or other nitrogen contents. The nitrate values are found to be higher in the Manohara and Nakhu Khola (Table 2, Fig. 4), which may be due to the effect of agricultural fertilisers.

The phosphate concentration (Tables 2 and 3 ) is high in the dry seasons (i.e., in winter and pre-monsoon period). It tends to rise abruptly at Minbhawan and continues to do so until the end of sampling point at Khokana (Fig. 1).

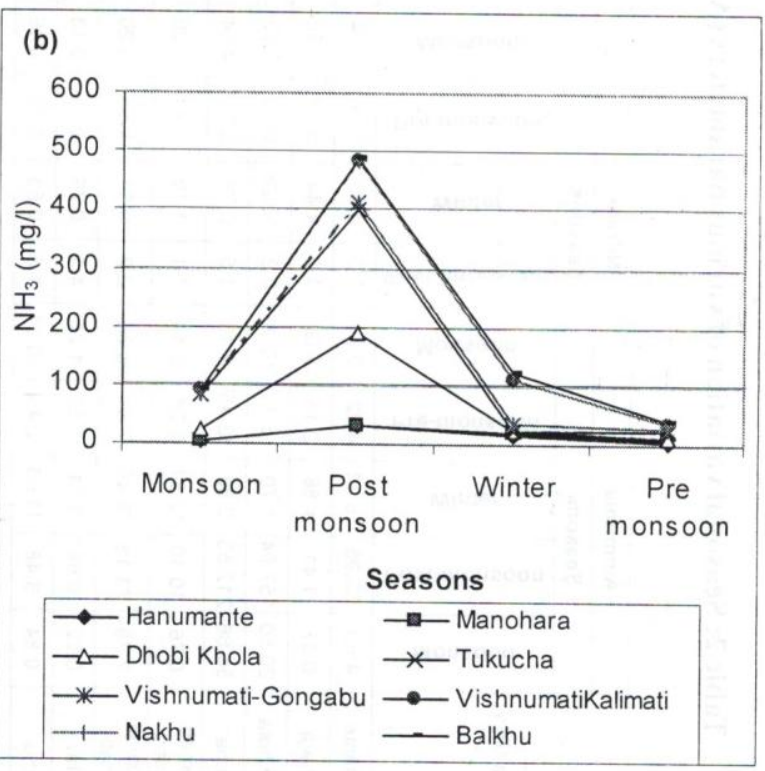

Fig. 3: Seasonal ammonia variation in (a) the Bagmati River and (b) its tributaries in 2002/2003 
มәุบ!M

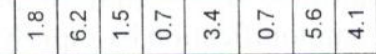

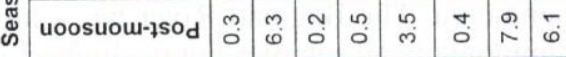

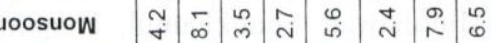
uoosuoul-2dd 

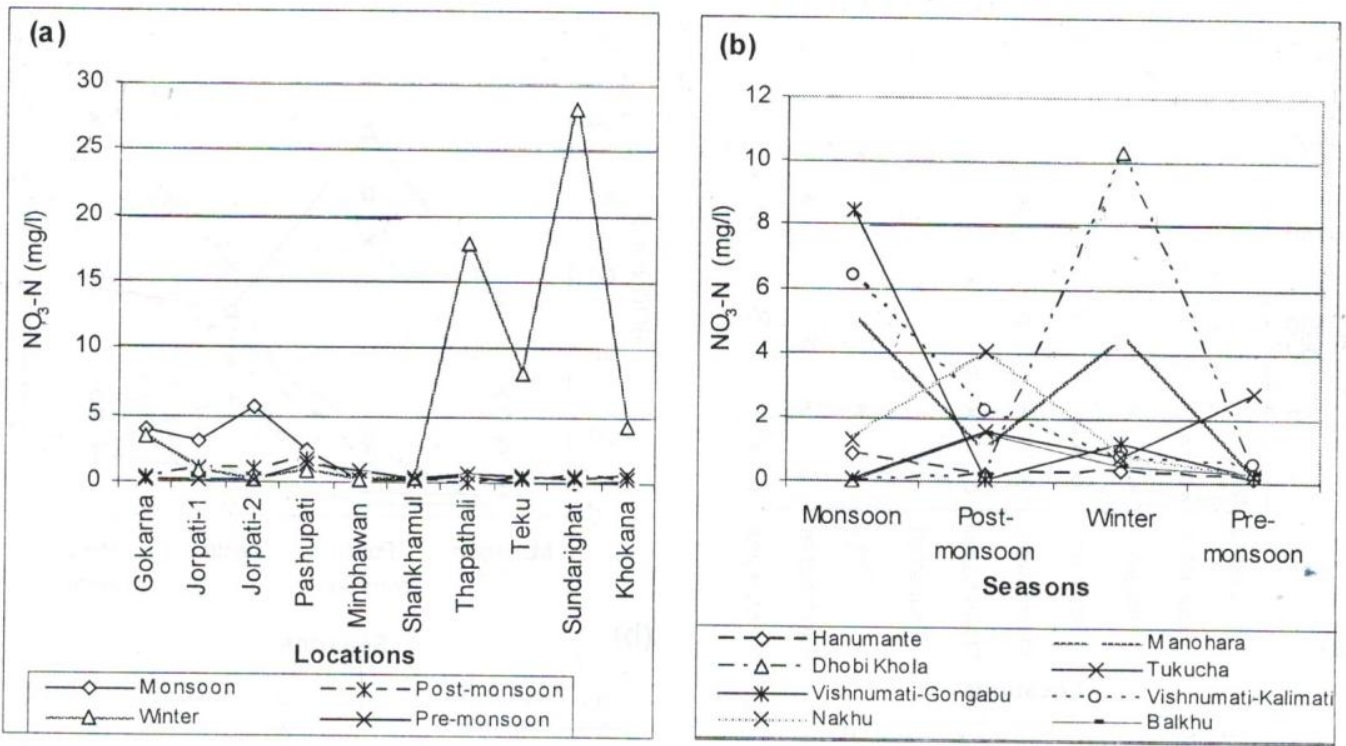

Fig. 4: Seasonal nitrate variation in (a) the Bagmati River and (b) its tributaries in 2002/2003
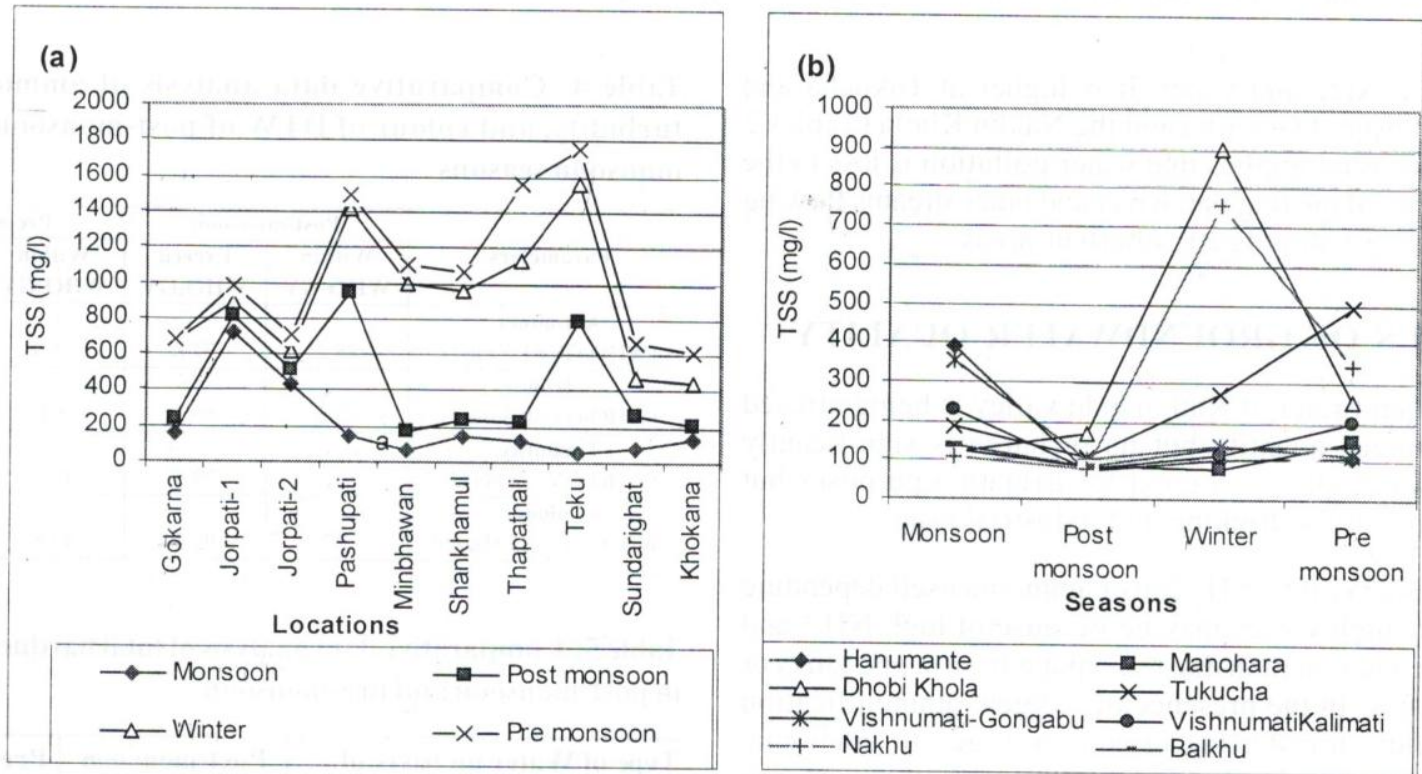

Fig. 5: Seasonal variation of total suspended solids in (a) the Bagmati River and (b) its tributaries in 2002/2003

The TSS value is also an indication of pollution. The TSS values are lower in samples from Gokarna, Jorpati, and Pashupati along the main stream as well as Nakhu and Balkhu among the tributaries (Fig. 5), which show that these rivers are less polluted in the suburban areas (Tables 2 and 3)). Because of the river water treatment plant installed near Pashupati, the water quality of this region is relatively better than the other sampling locations.

DO, BOD, and COD are oxygen-related parameters. DO give the measure of the amount of oxygen dissolved in water. A high DO value means abundance of dissolved oxygen indicating a lesser degree of pollution. The analytical data (Tables 2 and 3 ) showed that the DO values are higher near Gokarna and Nakhu Khola but very low in the areas where the Bagmati River traverses through the city (Fig. 6).

BOD is a measure of oxygen utilised by microorganisms for aerobic oxidation at $20^{\circ} \mathrm{C}$. The BOD values are high in all locations after flowing down from Pashupati due to the increasing pollution in the populated areas. Among the tributaries, the Dhobi Khola shows the highest value of BOD (Table 2, Fig. 6). Similarly, COD is a measure of oxygen required for oxidation of organic matter in water 

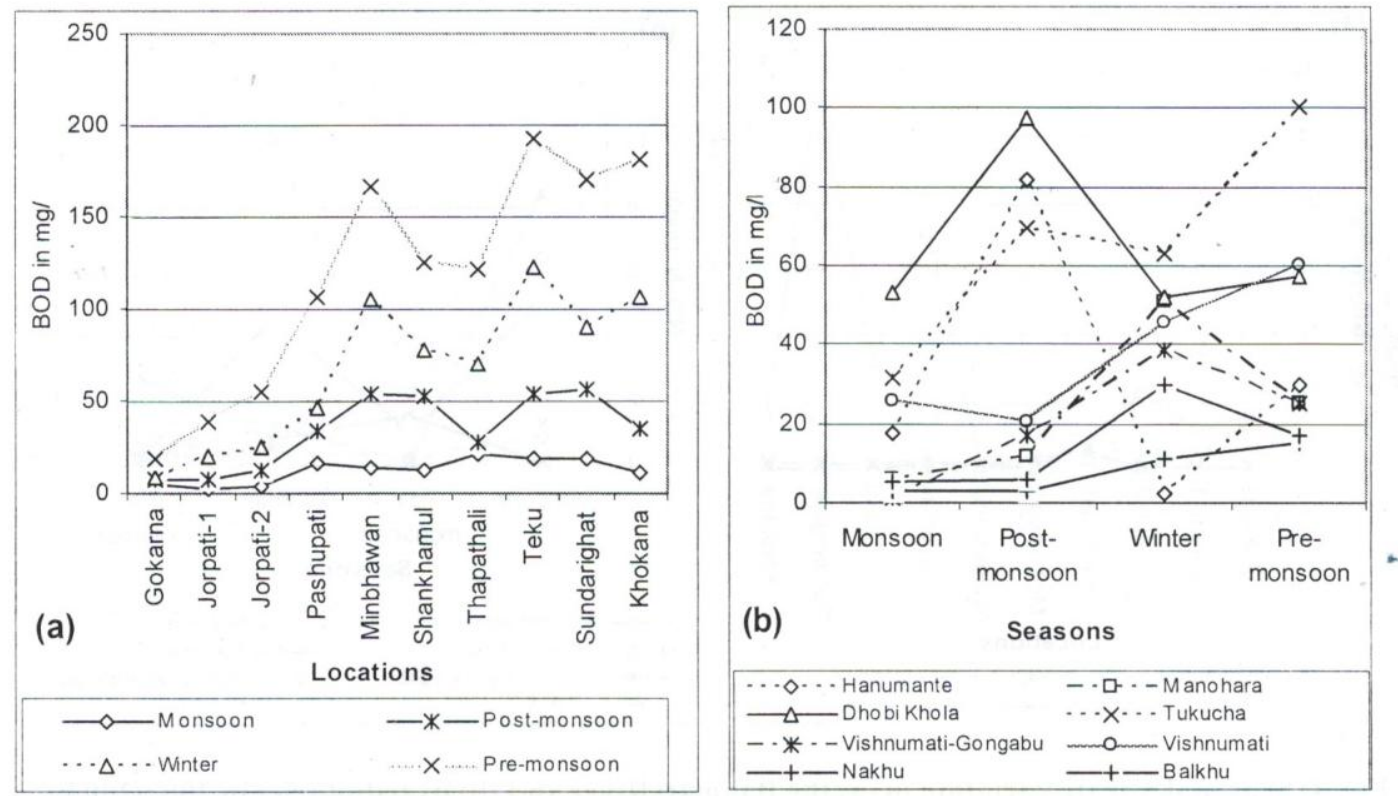

Fig. 6: Seasonal variation of BOD in (a) the Bagmati River and (b) its tributaries in 2002/2003

to carbon dioxide and water. It is higher at Tukucha and Teku, and lower at Gokarna and the Nakhu Khola (Tables 2 and 3). This trend implies that water pollution is less in the upper reaches of the Bagmati River and other streams flowing through the less populated suburban areas.

\section{STATUS OF GROUNDWATER QUALITY}

The groundwater of Kathmandu valley is being utilised in an enormous quantity but its recharge is significantly low. The water quality is good for irrigation purposes but needs treatment for drinking and industrial usage.

Ammonia exists as $\mathrm{NH}_{4}^{+}$ion or ammonia itself depending on $\mathrm{pH}$. The high values may be because of high $\mathrm{NH}_{4}^{+}$and microbial contamination due to seepage from septic tanks or animal wastes. In the presence of oxygen, ammonification occurs rapidly transferring organic nitrogen to ammonia. Ammonia is generally dominant relative to other nitrogen compounds like nitrite and nitrate. Nitrate is usually an indication of non-point source pollution. Common non-point sources of pollution are leaching of agricultural fertilisers, human and animal wastes, leachates from poorly designed septic systems, untreated sewage discharges, and leaky landfills. Excessive intake of nitrate in infants has been linked to methemoglobinemia, often referred to as the "blue baby syndrome", in which oxygen in the blood stream is depleted (Bittner 2000). Furthermore, intake of nitrate has been linked to rates of mortality from gastric cancer. High nitrate concentrations are usually found in shallow aquifers. However, nitrification of ammonia cannot occur in deep aquifers due to lack of oxygen but a high ammonia concentration can be found. The WHO guideline value $(\mathrm{GV})$ for ammonia in drinking water is $1.5 \mathrm{mg} / \mathrm{l}$ and about $84.6 \%$ of
Table 4: Comparative data analysis of ammonia, iron, turbidity, and colour of DTW of post-monsoon and premonsoon seasons

\begin{tabular}{c|c|c|c|c}
\hline \multirow{2}{*}{ Parameters } & \multicolumn{2}{|c|}{ Post-monsoon } & \multicolumn{2}{c}{ Pre-monsoon } \\
\cline { 2 - 5 } & $\begin{array}{c}\text { Within } \\
\text { WHO-GV }\end{array}$ & $\begin{array}{c}\text { Exceed } \\
\text { WHO-GV }\end{array}$ & $\begin{array}{c}\text { Within } \\
\text { WHO-GV }\end{array}$ & $\begin{array}{c}\text { Exceed } \\
\text { WHO-GV }\end{array}$ \\
\hline $\begin{array}{c}\text { Ammonia } \\
\text { (WHO-GV=1.5 mg/) }\end{array}$ & 28.2 & 71.8 & 15.4 & 84.6 \\
\hline $\begin{array}{c}\text { Iron } \\
\text { (WHO-GV=0.3 mg/l) }\end{array}$ & 10.3 & 89.7 & 5.1 & 94.9 \\
\hline $\begin{array}{c}\text { Turbidity } \\
\text { (WHO-GV = 5 NTU) }\end{array}$ & 23.1 & 79.5 & 35.9 & 64.1 \\
\hline $\begin{array}{c}\text { Colour } \\
\text { (WHO-GV =15 Hazen) }\end{array}$ & 7.7 & 92.3 & 43.6 & 56.4 \\
\hline
\end{tabular}

Table 5: Comparative data analysis of total hardness of DTW in post-monsoon and pre-monsoon

\begin{tabular}{c|c|c}
\hline $\begin{array}{c}\text { Type of Water on basis of } \\
\text { Hardness }\end{array}$ & $\begin{array}{c}\text { Post-mons oon } \\
\text { (\% wells })\end{array}$ & $\begin{array}{c}\text { Pre-mons oon } \\
\text { (\% wells })\end{array}$ \\
\hline Soft $(<60 \mathrm{mg} / \mathrm{l})$ & 38.5 & 18 \\
\hline Mod. Hard $(61-120 \mathrm{mg} / \mathrm{l})$ & 18.0 & 31 \\
\hline Hard $(121-180 \mathrm{mg} / \mathrm{l})$ & 23.1 & 15 \\
\hline Very Hard $(>180 \mathrm{mg} / \mathrm{l})$ & 20.5 & 36 \\
\hline
\end{tabular}

DTW of Kathmandu valley (Table 4 ) exceed this value in pre-monsoon season and $71.8 \%$ DTWs (Fig. 7) exceed in post-monsoon season. In dry season the depletion of water table below the riverbeds can possibly cause their recharge with polluted water.

A high concentration of dissolved iron, $\mathrm{Fe}(\mathrm{II})$, is by far the most common water quality problem associated with the 

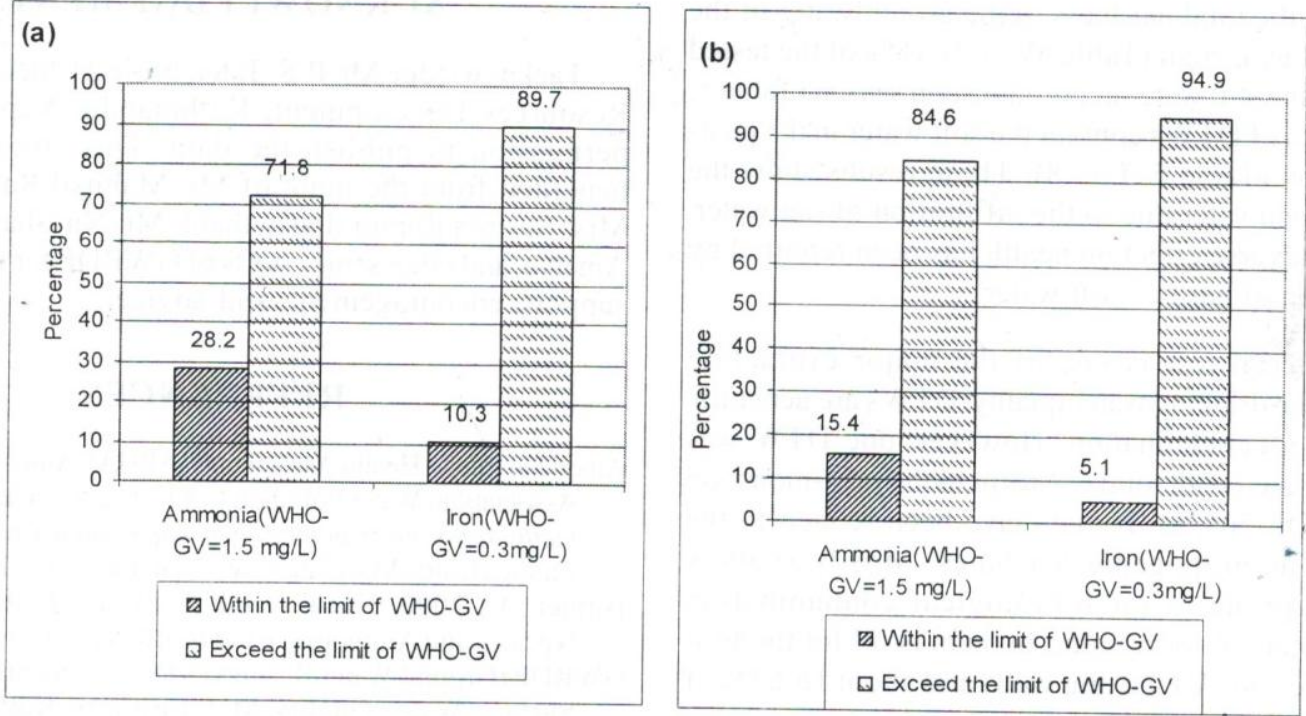

Fig. 7: Ammonia and iron concentrations in deep tubewells of the Kathmandu valley in (a) post-monsoon 2002 and (b) premonsoon 2003
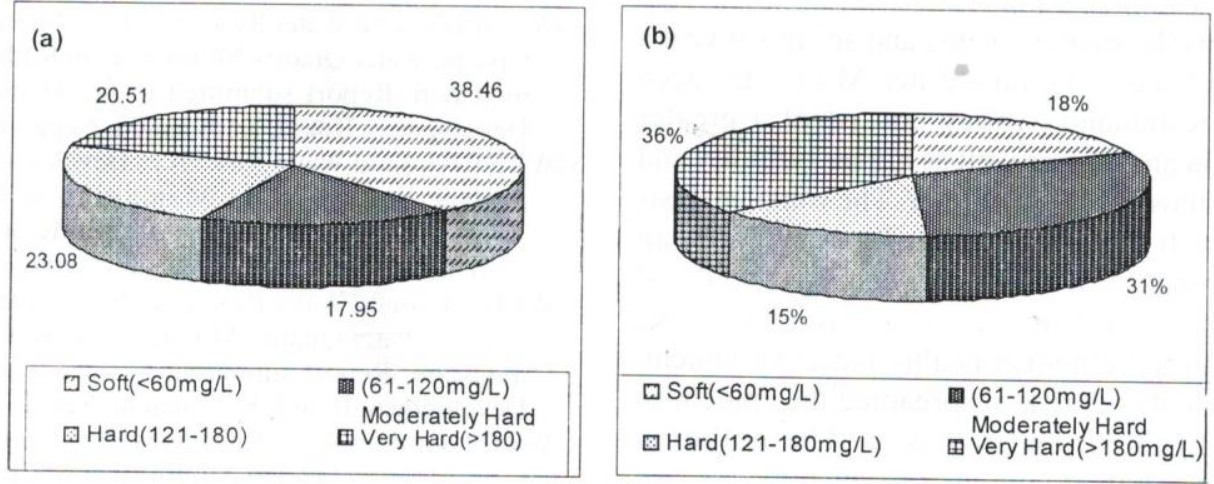

Fig. 8: Classification of deep tubewells of the Kathmandu valley on the basis of hardness (as $\mathrm{CaCO}_{3}$ ) in (a) post-monsoon 2002 and (b) pre-monsoon 2003

Table 6: Comparative data analysis of total Coliform test in post-monsoon and pre- monsoon

\begin{tabular}{l|c|c|c|c}
\hline \multirow{2}{*}{ Type of tubewell } & \multicolumn{2}{|c|}{ Post-monsoon } & \multicolumn{2}{c}{ Pre-monsoon } \\
\cline { 2 - 5 } & Total coliform & Faecal coliform & Total coliform & Faecal coliform \\
\hline DTW & 5.1 & 0.0 & 0.0 & 0.0 \\
\hline STW & 0.0 & 0.0 & 0.0 & 0.0 \\
\hline Dug well & 100.0 & 33.3 & 100.0 & 66.7 \\
\hline Spring & 33.3 & 16.7 & 16.7 & 16.7 \\
\hline
\end{tabular}

groundwater. Even shallow wells contain a high iron concentration, and the water must be treated for drinking as well as industrial usage. Iron also damages agricultural productivity due to the low $\mathrm{pH}$ value in ferric hydroxide-rich soils. The WHO GV of iron is set as $0.3 \mathrm{mg} / \mathrm{l}$. The analysis (Table 4; GWRDP 2003c) shows that $94.9 \%$ of DTWs exceed this value in the pre-monsoon season (Fig. 7).
The values for colour and turbidity of groundwater analysed in post-monsoon and pre-monsoon season show that the percentage of wells exceeding the WHO GV is higher in the post-monsoon than in the pre-monsoon season (Table 4). Infiltration and percolation of rainwater through the wet soil into the aquifer may be the cause of high colour and turbidity values. 
In general, the total hardness in the groundwater of the Kathmandu valley is high (Table 5). Only $18 \%$ of the tested DTWs possess the soft water in pre-monsoon season (Table 5 , Fig. 8), and $38 \%$ of DTWs contain the soft water in the postmonsoon season (Table 5, Fig. 8). These results show the dilution of groundwater due to the infiltration of rainwater. Generally, no adverse effect on health has been reported by the consumption of hard or soft water.

Micro bacterial test is one of the major evaluating parameters of the drinking water quality. DTWs are generally free of coliform contamination. However, one DTW was found contaminated with total coliform in the post-monsoon season (GWRDP 2002c). It may have been related to the infiltration of anthropogenic leachates. Mostly shallow tubewells are prone to microbiological contamination although the total coliform found in them is nil for the four shallow wells tested. All the dug wells and about $16.67 \%$ of springs were found to be contaminated (Table 6).

\section{CONCLUSIONS AND DISCUSSIONS}

The surface and subsurface water in the Kathmandu valley is highly contaminated. The water samples taken from various deep tubewells, shallow wells, and springs reveal a remarkable contamination of groundwater. Most of the deep tubewells of the Kathmandu valley consist of a greater amount of ammonia and iron as well as higher turbidity and colour values than those of the WHO GV. The water analysis data of the Bagmati River and its tributaries show an increasing contamination trend in the densely populated areas. Bad odours rising from the sewage and riverbeds have an adverse impact on the human health and environment. Further, there is also a high risk of spreading the epidemics such as cholera, typhoid, and jaundice. The pollution problem has arisen mainly due to the human activities like indiscriminate disposal of domestic sewage, wastewater, and industrial effluents. If wastewater treatment methods are applied, the water quality of the Kathmandu valley can be improved significantly.

\section{ACKNOWLEDGEMENTS}

I acknowledge Mr. P. S. Tater, Project Chief, Ground Water Resources Development, Kathmandu, Nepal, for giving permission to publish the data. This study was greatly benefited from the input of Mr. Mahipal Ram Baidya and Mrs. Sushila Regmi. I also thank Mr. Nir Shakya, Mr. S. M. Amatya, and other senior staffs of GWRDP for their invaluable support, encouragement, and advice.

\section{REFERENCES}

American Public Health Association (APHA), American Water Works Association, Water Pollution Control Federation, 1995, Standard methods for the examination of water and wastewater. American Public Health Association, Washington D. C., 19th ed.

Bittner, A., 2000, Nepal Drinking Water Quality Assessment: Nitrates and Ammonia, www.thinkcycle.org/tc

GWRDP (Ground Water Resources Development Project), 2002a, Surface Water Quality Monitoring in Kathmandu Valley, Monsoon. Report submitted to the Melamchi Water Supply Development Board, Kathmandu, Nepal, 18 p. (Unpublished).

GWRDP (Ground Water Resources Development Project), 2002b, Surface Water Quality Monitoring in Kathmandu Valley, Postmonsoon. Report submitted to the Melamchi Water Supply Development Board, Kathmandu, Nepal, 18 p. (Unpublished).

GWRDP (Ground Water Resources Development Project), 2002c, Ground Water Quality Monitoring in Kathmandu Valley Postmonsoon. Report submitted to the Melamchi Water Supply Development Board, Kathmandu, Nepal, 18 p. (Unpublished).

GWRDP (Ground Water Resources Development Project), 2003a, Surface Water Quality Monitoring in Kathmandu Valley, Winter. Report submitted to the Melamchi Water Supply Development Board, Kathmandu, Nepal, 18 p. (Unpublished).

GWRDP (Ground Water Resources Development Project), 2003b, Surface Water Quality Monitoring in Kathmandu Valley, Premonsoon. Report submitted to the Melamchi Water Supply Development Board, Kathmandu, Nepal, 18 p. (Unpublished).

GWRDP (Ground Water Resources Development Project), 2003c. Ground Water Quality Monitoring in Kathmandu Valley Premonsoon. Report submitted to the Melamchi Water Supply Development Board, Kathmandu, Nepal, 18 p. (Unpublished).

Warner, N., 2001, Geology, Ground Water Quality in Nepal's Kathmandu Valley: An assessment of controlling site characteristics, www. gsa.confex.com Miami University 